\title{
Exploring the Instructional Strategies of Elementary School Teachers When Developing Technological, Pedagogical, and Content Knowledge via a Collaborative Professional Development Program
}

\author{
Shih-Hsiung Liu ${ }^{1}$ \\ ${ }^{1}$ Center for Teacher Education, National Changhua University of Education, Changhua, Taiwan \\ Correspondence: Shih-Hsiung Liu, Center for Teacher Education, National Changhua University of Education, \\ No. 1, Jin-De Road, Changhua, Taiwan. Tel: 886-4-723-2105. E-mail: shsiung@cc.ncue.edu.tw
}

Received: September 4, 2013 Accepted: October 8, 2013 Online Published: October 15, 2013

doi:10.5539/ies.v6n11p58

URL: http://dx.doi.org/10.5539/ies.v6n11p58

The research is financed by National Science Council of Taiwan under contract No. NSC-100-2410-H-018-018

\begin{abstract}
The technological, pedagogical, and content knowledge (TPACK) framework has been regarded as potentially effective in helping teachers integrate technology into the classroom. This study explores the instructional strategies of teachers when developing TPACK. A teacher professional development (TPD) program, in which teaching activities and deep discussions were key processes, was conducted. Instructional observations and focus-group interviews were the primary evaluation methods. Six elementary school teachers participated in this program between September 2011 and January 2012. Analytical findings demonstrate that teachers initially had limited pedagogical knowledge (PK). For intentional use of technology during teaching, the teachers transformed technology operating skills into multiple teaching activities for content learning, and expanding their TPACK base. The teachers then applied PK basis and combined them with subject content and technology through the TPD program, and reorganized their application of TPACK. Moreover, teachers engaged in peer observation and group interviews during TPD, effectively built TPACK. This study provides teacher educators who are interested in examining teachers' TPACK with an effective TPD program for technology integration. We recommend that teacher educators continually enhance the technological knowledge of teachers and promote TPACK through collaborative TPD programs.
\end{abstract}

Keywords: technological pedagogical and content knowledge (TPACK), technology integration, teacher professional development

\section{Introduction}

Teachers are encouraged to use technology to enhance student learning while teaching, emphasizing that teachers applying technology in educational settings should focus on pedagogical goals rather than technological innovation (Angeli \& Valanids, 2009). However, some studies have indicated that technology integration by teachers in the classroom is insufficient (Ertmer, 1999; Ertmer, 2005; Park \& Son, 2009). This observation has led to analyses of technology integration by teachers (Gülbahar, 2007; Güyer \& Sahin, 2011; Jang, 2008; Liu, 2011). Mishra and Koehler (2006) expanded the idea of Pedagogical Content Knowledge (PCK) described by Shulman (Shulman, 1986), and developed the Technological, Pedagogical and Content Knowledge (TPACK) framework, which is the complex interplay among three primary knowledge forms: Content Knowledge (CK), Pedagogical Knowledge (PK), and Technological Knowledge (TK). The TPACK framework can help teachers remedy insufficient technology integration.

Mishra and Koehler argued that three other sources of knowledge can be derived from the interactions among CK, PK, and TK, namely, PCK, Technological Content Knowledge (TCK), and Technological Pedagogical Knowledge (TPK). The PCK deals with teaching processes (Shulman, 1986), and combines content and pedagogy to develop enhanced teaching practices in subject content areas. The TCK refers to knowledge about how technology can be used to provide new ways of teaching content (Niess, 2005). The TPK is knowledge of how various technologies can be used while teaching (Schmidt, Baran, Thompson, Mishra, Koehler, \& Shin, 
2009), and also hints at the affordability and constraints of technology as an enabler of different teaching approaches (Mishra \& Koehler, 2006).

The TPACK framework is a potentially fruitful model that provides new directions for teachers in integrating technology into instruction (Hewitt, 2008), and describes the knowledge teachers require when designing, implementing, and evaluating curricula and instruction using technology (Niess, 2011).

However, whether teachers know what, when, and how to use domain-specific knowledge and strategies to guide student learning with appropriate digital, information, and communication technologies is a critical issue (Neiss, 2011). Designing instructional strategies in applying TPACK is an iterative process in which teachers must actively engage students in transforming, organizing, and reorganizing their experiences. Teachers must also teach content using appropriate technology based on their knowledge (Niess, 2012) and beliefs (Ertmer, 2005). Teachers working in a collaborative group can share ideas, discuss issues, and then innovatively apply TPACK. Harrington (2008) recommended that when examining the TPACK of teachers, one must consider the combination of the social and cognitive perspectives as a tool for framing and characterizing how teachers develop knowledge for teaching with technology. Boling and Beatty (2012) further indicated that school administrators, teachers, and individuals who collaboratively design professional development opportunities should gradually introduce teachers to the complexities surrounding technology integration and provide additional support systems during this process.

These perspectives on technology use in classrooms have been realized to a certain extent. Most early teachers were currently not prepared to engage in strategic thinking about the use of TPACK (Niess, 2011), especially elementary school teachers, who were expected to enhance student learning with technology. Several TPACK surveys were conducted to identify pedagogical approaches for teachers (Archambault \& Barnett, 2010; Chai, Koh, Tsai \& Tan, 2011; Schmidt et al., 2009); however, these studies did not fully characterize the collaborative development of teachers. That is, elementary school teachers developing their TPACK of technology integration through collaborative professional development is a worthy focus. Thus, this study explores the instructional strategies of teachers developing their TPACK through a collaborative educational setting.

\section{Literature Review}

\subsection{Application of Teachers' TPACK}

Koehler and Mishra (2009) indicated that effective technology integration for teaching subject content requires knowledge of content, technology, and pedagogy, and their interrelationships. In addition to the need for teachers to have a deep understanding of CK and PK (Shulman, 1986), technology integration requires an understanding of how technology transforms subject content and instructional strategies into innovative teaching activities.

Technology can change how subject content is presented. However, teachers must understand which technologies are best suited to subject content and understand how content dictates or perhaps even changes technology (Koehler \& Mishra, 2009). To maintain a student focus and to convey messages clearly, teachers must excel in presentation. Whether subject content is approved and accepted by students depends on its difficulty level and how it is presented. Yalçın and Yalçın (2010) suggested that presentations of subject content should be considered because presentation plays a key role in motivating, convincing, and focusing the attention of students. Notably, teachers need be cognizant of the fact that the most popular software programs are not designed for educational purposes, and should develop the skills needed to move beyond the immediate technology and reconfigure it for their own pedagogical purposes. This means that technology use in classrooms should advance student learning and understanding. Thus, teachers should be aware of the affordability and constraints of technologies, and be able to identify how various technologies can be used while teaching.

Jang (2010) conducted a study that used an integrated interactive whiteboard (IWB) and peer coaching help secondary school science teachers develop TPACK in classrooms. Each teacher selected an appropriate teaching strategy or presentation to integrate IWB technology according to knowledge acquired from academic studies or books. Jang concluded that IWBs helped science teachers who encountered teaching difficulties in the traditional classroom setting better implement their presentations and instructional strategies. Inan, Lowther, Ross and Strahl (2010) examined the relations between types of computer applications and teachers' classroom practices based on data gathered from direct classroom observations obtained during 143 lessons. Their study revealed that classroom practices were typically student centered when students used a computer as a learning tool for, say, accessing the Internet, word processing, and presentations.

Currently, teachers are expected to practice student-centered or constructivist learning via technology use in classrooms. From a pedagogical perspective, van Braak (2001) argued that technology use in educational 
settings fosters collaborative learning, provides flexible learning opportunities, and facilitates learning independent of time and place. Additionally, technology use in classrooms by teachers is not only concerned with technological skills, but also emphasizes student practices by providing students with collaborative and active learning environments (Bauer, \& Kenton, 2005; Jonassen, Howland, Moore, \& Marra, 2003). Thus, teachers should be equipped with instructional strategies for student-centered learning to form integrated knowledge of how various technologies can be used while teaching.

Studies indicated that teachers should initially acquire primary TK, including technological competencies and basic software skills (Snoeyink \& Ertmer, 2002; Zhao \& Cziko, 2001). The TK of teachers can help them understand the functions and capacity of a technology and how each technology application may benefit student learning. Once teachers become familiar with a technology, teacher training should focus on how to use that technology for such student-centered learning tasks as collaborative learning and high-order questioning, and encourage student independence and facilitate student learning (Ertmer, 2005; Windschitl \& Sahl, 2002). These perspectives indicate that facilitating the application of TPACK by teachers can start with TK construction, and then combine TK with PK and CK to form TPACK. Therefore, under the condition of a deep understanding of $\mathrm{CK}$, equipping teachers with technology gradually and promoting current teacher practices with continuous support will effectively enhance teacher use of technology as a learning tool (Cooley, 2001; Snoeyink, \& Ertmer, 2002). The TPACK can also be developed as a student-centered pedagogy with technology use for content learning.

\subsection{Development of Teachers' TPACK}

Teachers must develop fluency and cognitive flexibility in each key domain (i.e., TK, PK, and CK) and in the manner in which these domains are interrelated (Koehler \& Mishra, 2009). As mentioned, teacher professional development (TPD) programs using collaborative participation can promote the ability of teachers to integrate technology into instruction. Koehler, Mishra and Yahya (2007), who designed a TPD program in which teachers worked with graduate students to develop online courses, reported that participants moved from considering technology, pedagogy, and content as independent constructs toward a richer conception that emphasized connections among the three knowledge bases. Koehler et al. described developing TPACK as a multigenerational process, involving the development of a deep understanding of the complex web of relationships among content, pedagogy, technology, and the contexts in which they function.

Niess, van Zee and Gillow-Wiles (2010) developed a three-year online master's degree program focused on integration of technology with science and mathematics instruction and learning. All twelve K-8 teachers, who initially had no experience incorporating spreadsheets into teaching, valued the opportunities to experiment with spreadsheets while they learned about how they could use spreadsheets to support connections between mathematics and science content. Niess et al. concluded that teacher development from recognizing to accepting, adapting, and exploring TPACK levels indicated that teachers' views of spreadsheets as instructional tools were fundamental in evaluating how spreadsheets were used when teaching science and mathematics.

Mishra, Kolehler, Shin, Wolf and DeSchryver (2010) proposed a leaning-by-design direction to TPACK development, and further indicated that teachers were prepared to reflect on pedagogy, technology, and content and their interrelationships when considering a difficult instructional problem. Mouza and Wong (2009) proposed a TPACK-based case development strategy in which teachers learned from practice. These studies indicated that while teachers are involved in instructional practices using TPACK, they can engage in strategic thinking about how to design teaching activities that use technology. Jimoyiannis (2010) conducted an empirical study that investigated the perceptions of technology of four science educators, and evaluated the TPACK framework and the approach followed during course sessions. Participants reported their ability to view technology, pedagogy, and science knowledge as an integrated and interrelated construct rather than as separate elements increased. The TPACK helped participants perceive and develop a new understanding of instruction and clarified many instruction-related issues. All participants reported an increased willingness and confidence in their ability to apply technology to their instruction.

Several studies have proved that TPD programs can promote effective technology integration (Harris \& Hofer, 2011; Overbaugh \& Lu, 2008). Inan et al. (2010) demonstrated the effectiveness of a TPD program in which teachers observed experienced teachers first and then practiced. The teachers could share their experiences and learn from each other by working together in a teacher group. Thus, using a collaborative method helps teachers develop their TPACK, as well as explore their strategic understanding of TPACK.

Although some studies indicated that teachers perceive the effectiveness of expanding technology integration, most studies did not identify the perspectives of teachers or explore how teachers develop TPACK in real 
classrooms. Angeli and Valanides (2009) argued that the conceptualization of TPACK requires further theoretical clarity and criticized TPACK for not making explicit the relationships among subject content, pedagogy, and technology. This study explores the instructional strategies of teachers in developing TPACK in educational settings. The specific research questions are as follows.

1) What are teachers' initial implementations of technology integration? How do teachers change their application of TPACK to teaching after participating in a collaborative TPD program?

2) How does the collaborative TPD program facilitate the change to instructional strategies of teachers in referring to the TPACK framework? How does this change make explicit the connections among subject content, pedagogy, and technology?

\section{Research Methodology}

As mentioned, this study explores the instructional strategies of teachers in developing TPACK through a TPD program. According to Birman, Desimone, Garel and Porter (2000), successful professional development built on previous activities with a specific goal, offered teachers opportunities to discuss classroom experiences with other teachers, and encouraged ongoing professional communication for dealing with similar concerns. Thus, the researcher organized a teacher group in which both teaching activities and deep discussions were key processes. Instructional observations and focus-group interviews (FGIs) were the primary analytical methods. All data were used to analyze what was occurring while developing TPACK, and to explore the causes of changes in teacher performance in technology integration, as well as the effects of the TPD program.

\subsection{Participants}

Teachers from two neighboring elementary schools in Taiwan were invited to discuss this TPD program with the researcher. Finally, six teachers were willing to participate in this program. The teachers' average age was 38 (range, 26-40), and their average number of years teaching was 9 (range, 3-20). Each teacher taught different subjects, including Language Arts (fifth grade), the English language (sixth grade), Social Studies (sixth grade), Science and Technology (third grade), Mathematics (fifth grade), and Life Curriculum (first grade). No teacher had graduated from a technology-related academic department; that is, they had only a general understanding of technology use in the classroom. Before participating in this program, all teachers reported their experiences in using technology in the classroom; however, none had heard of TPACK.

\subsection{Professional Development Program}

In this study, a well-intentioned TPD program was designed to help teachers develop an initial understanding of TPACK. Shulman (1987) asserted that the PCK development process may pass through comprehension, transformation, instruction, evaluation, reflection, and new comprehension. Harrington (2008) recommended that when examining teachers' TPACK, one must consider the social and cognitive perspectives combined as a tool for framing and characterizing how teachers develop knowledge for teaching with technology. Thus, this well-intentioned TPD program, which integrates Shulman's PCK development process and social interaction from the work by Harrington, had five stages: comprehension; transformation and lesson design; instruction and peer observation; discussion; and, FGIs. To obtain sufficient information from teachers about TPACK, the TPD program cycled through the following last four stages.

First, all members participated in a workshop in which all teachers were taught about how to use TPACK when designing integrated courses that combine subject content, technology, and pedagogy. Second, each teacher designed a lesson by referring to the TPACK framework, and uploaded this lesson to the study's website for review by other teachers. Each teacher could offer suggestions to any lesson on the website. The lesson designer could then revise the lesson. Third, each teacher implemented the revised lesson in their classroom and was observed by other teachers. The teacher's instruction was recorded by a digital video camera, providing the researcher and other teachers with an opportunity for subsequent analysis. Fourth, each observer was encouraged to take field notes about technology integration and to post these notes on a discussion forum on the study's website. Informal discussions, such as face-to-face discussions and those through email, were also encouraged. Each instructor was required to respond to observer comments. Fifth, one FGI was held. All members repeated the last four stages four times between September 2011 and January 2012.

\subsection{Instructional Observations}

Each teacher was asked to observe other teachers teaching, their utilization of technology and instructional strategies, and the chosen subject content. Instruction in each class was videotaped for subsequent analysis and was documented by the researcher using field notes consisting of a general description and interpretations. Analysis of observations started with data collection. Emerging themes about changes in teachers' opinions of 
TPACK were confirmed or reconstructed with new data until data repeatedly confirmed themes. The researcher also compared similarities and differences in the instructional strategies of teachers among TPACK components via a cross-case analysis.

\subsection{Focus Group Interview}

The FGIs were used to identify how TPACK was developed, to identify changes and their causes as professional development outcomes, and to confirm the details of instructional strategies. The focus groups consisted of all participants and the researcher to ensure a wide range of opinions. In this study, the FGI was used to collect quality data in a collaborative group setting, which allowed all teachers in interactive group settings to offer opinions, compare and contrast their views with those of others, and further develop a broad and deep understanding of TPACK application.

An FGI was held after each lesson. Initial questions were based on research questions and those in a study by Boling and Beatty (2012), who explored tensions and challenges associated with technology integration with TPD. All questions were reviewed by five professors to improve their clarity and content validity. Revised questions were as follows.

(a) According to your teaching activities with technology in this lesson period, how did these activities relate to TK, PK, and CK?

(b) What changes have you made to lesson plans and teaching practices that were related to subject matter, pedagogy, technology and their relationships?

(c) Please describe why this change happened.

(d) Based on what, when, and how to integrate technology into classroom instruction, please describe your opinions about subject content, pedagogy, and technology.

In addition to these questions, progress data related to research questions, including designed lessons, videotaped films, and comments on the website, were also reviewed to identify issues that must be discussed during each FGI.

The FGIs were semi-structured and videotaped. After each FGI, data were analyzed. Analysis of FGIs involved transcript reviews to determine what the group said about each issue and to draw conclusions. Indexing was the analytical method. Whenever a pattern of teachers' perspectives on TPACK emerged, the researcher reviewed the pattern again to identify relationships and trends among various comments and discussion data.

\section{Findings}

The analytical result of the study reveals two emergent themes that characterize teachers' presentation of and instructional strategies about TPACK. Through the first theme, transformation, this study indicates the teachers' changes in teachers' opinions of TPACK. Another emerging theme, reorganization, describes the change to instructional strategies of teachers.

\subsection{Teachers Expand Their TPACK by Transforming Technology Operating Skills into Multiple Teaching Activities for Content Learning}

Before participating in the program, most participant responses suggested that using an IWB to lecture on a subject was the main teaching activity in classrooms. The teachers had learned several ways of using technologies, such as using animated pictures that were installed in the IWB. Additionally, some teachers had designed simple interactive digital multimedia presentations for instructional material. Moreover, all teachers reported they used the Internet, PowerPoint, the YouTube website, electronic books, and laptops frequently while teaching. In terms of subject content, teachers realized that abstract concepts, which are difficult for students to learn, are suited to the use of digital animated pictures. Multimedia with photographs and audio and video materials could be used teaching subject content, especially for listening to and speaking in the English language. As two teachers stated,

Technology is just similar to a wall chart on the backboard that facilitates students' understanding of subject content. In terms of the IWB, I am used to utilizing click and drag function to lecture on subject content. (Teacher A, first FGI)

I designed several pictures and attached different voices to them to teach English. My students were interested in the lesson when I utilized them while teaching.... I also searched several multimedia sites on the Internet and downloaded a few of English films related to subject content when I lacked the time needed to design instructional multimedia...(Teacher F, first FGI) 
These statements reveal that different technological functions were employed to teach different subject content. That is, teachers utilized two types of TCK by combining subject content with the IWB and with multimedia. However, teachers reported that they primarily lectured while teaching. Briefly, the teachers present multiple types of TCK under the condition that technology use was intentional, while their PK was insufficient. Furthermore, some teachers were equipped with various technological skills for designing digital content, such that their TCK was identified easily while they taught. Conversely, TPK and PCK of teachers were deficient due to a lack of multiple types of PK. Jang and Tsai (2012) indicated that Taiwanese elementary teachers who used IWBs rated themselves significantly higher in CK, PCK in context (PCKCx), TK, and TPACK in context (TPCKCx) than did teachers who did not use IWBs. However, Jang and Tsai only analyzed the effect of PCKCx, and did concretely discuss teachers' PK. Limited PK may result in poor teaching practices and difficultly developing different teaching approaches for technology integration.

Fortunately, this problem was not a large worry. Chai et al. (2011) concluded that PK had a direct impact on TPACK, indicating that limited PK may weaken TPACK, while this direct relationship between PK and TPACK was insignificant when teachers made connections between their TK and PK to form TPK while teaching. Chai et al. further indicated that the direct effect of PK on TPACK after a course was mediated by TPK. They inferred that the course tending to pedagogical use of technology was likely the cause of such a change. That is, if teachers attempt to use technology while teaching in the same manner as they use it in their lives, they might develop additional instructional strategies. For instance, teachers familiar with the Internet can provide large amounts of information, and thus, they may guide students to use the Internet to search for information in inquiry-based learning. Instead of lecturing, teachers may equip students with the skills needed for inquiry-based learning, including searching for data and analyzing, comparing, and evaluating information, and ask students to achieve a learning task.

These phenomena were observed in teaching activities after the midst of the TPD program. During the third lesson period, Teacher D taught students how to use a digital camera, and then asked them to take photographs of the local community and present their photographs with oral descriptions when learning Social Studies content. These teaching activities differed from lecturing and tend to be a more student-centered use of technology. Teacher $\mathrm{D}$ admitted that the designed teaching activity was entirely for using a digital camera, which differed from her daily teaching style.

The lesson sheet was posted on the website and the third FGI recorded similar statements.

1) To watch the film called "Beautiful World" and local community photographs. 2) To discuss the ideal of local community. 3) To describe issues associated with an adequate living environment. 4) To take several photographs on the street corner that needs to be re-established. 5) To finish the learning sheet called re-establishing the local community. 6) To present group reports. (Teacher D, third lesson sheet)

I initially thought that I liked taking pictures with a digital camera. Maybe I could teach my students to do that. Thus, I decided to change the Social Studies teaching schedule to teach students how to use a digital camera. (Teacher D, third FGI)

These statements indicate that using technology expanded the teacher's thinking about teaching activities, and may reveal multiple instructional strategies to suit a technology's function. Analytical results and the literature review confirm that teachers' PK varied due to the use of various technologies. This finding clearly reveals that teachers were deficient in PK, while technology use made their limited PK expand. Further, this finding also confirms a finding obtained by Jang and Tsai (2012), who inferred that pedagogical use of technology may mediate the effect of PK on TPACK, transforming CK into TPACK.

\subsection{Teachers Applied PK Basis to Reorganize TPACK during the Collaborative TPD Program}

Teachers initially used lecture-based teaching activities with technology. However, after participating in the TPD program, teachers gradually developed student- centered teaching methods with technology. In addition to the previously inferred reasons for tailoring instruction to various technological functions, an analysis of teachers participating in the TPD program identified this change.

Initially, teachers were concerned about how to use digital technology, rather than choosing instructional strategies and subject content. Some teachers, who have good technology skills, may be very interested in the use of innovative technology, and can easily modify materials downloaded from the Internet for instruction, and sometimes, design instructional multimedia content themselves; however, a few participant teachers could not complete these tasks. This means that depending on TK to expand TPK is not sufficient, since all teachers may 
not have the necessary technological skills. Teacher F reported the following on the website forum during the second lesson period.

I teach English-language arts. Before, most of my teaching activities were reading and repeating. I had poor technology skills until I was taught how to utilize the IWB. I know that I can instruct one or two students to do something on the IWB, but I still have no alternative idea for teaching English. (Teacher F, Web)

Peer observation and interaction between teachers affected the development of instructional strategies, especially for this English arts teacher, as she reported.

I observed Teacher D in the last period and saw her teach students to discuss several photographs that were taken in the local community. I believe that her group discussion was highly effective. Teacher D told me that constructivist technology integration was easy as long as you were well prepared, and it did not require high technological skill. Thus, I tried to design a discussion activity that asked students to anchor the meanings of some images in a digital English-language picture book. Most students could describe the pictures after practicing in the group discussion. (Teacher F, fourth FGI)

A picture or a photograph may imply some meanings and is usually used as instructional material. If a teacher just lectures, students may have difficulty comprehending the multiple meanings of a picture. Providing students with discussion opportunities to compare different perspectives with each other can help students construct their own knowledge. A discussion strategy is suited to teaching about such pictures. In this study, Teacher $\mathrm{F}$ learned about a group discussion for digital pictures after observing Teacher D, and then employed it well. The collaborative teacher group seemed to have had a beneficial effect.

After the fourth lesson, teachers reported that teaching observations, comparisons with colleagues during FGIs, and further examining their own teaching methods are crucial components of teacher change.

Prior to participating in this study, I believed that technology integration was just a method teachers use to present something on a screen. However, after observing Teacher D's extended activities on traffic and the life unit in Social Studies (i.e., taking students to a computer lab and guiding them in searching for information for worksheet questions regarding a travel plan with a vehicle) and participating in group interviews, I believe that I obtained inspiration to combine subject content, technology use, and instructional strategies. (Teacher B, fourth FGI).

...group interviews were helpful in designing lessons that apply TPACK. I think merely observing instruction rarely results in new perspectives. Instead, I generated innovative ideas during group interviews. I think that listening to other teachers during interviews and comparing their perspectives with mine helped me develop effective teaching methods with technology. (Teacher C, fourth FGI).

All teachers were satisfied with their development in technology integration. Teachers stated that they gradually learned about ways to apply TPACK and its components.

I know that some subject content is not necessarily suited to technology use during teaching. In the last two weeks, to save time, I obtained a film about electrical conduction and presented it on the IWB instead of using an actual scientific experiment activity. I learned that learning effectiveness of students was worse than ever, even though students who utilized the IWB were highly interested. (Teacher A, fourth FGI)

I agree with Teacher A. We have learned that multiple instructional strategies should be considered with technology. I found that my students really liked the group discussion. Maybe I can let students discuss expanded questions on a website. (Teacher F, fourth FGI)

Teachers altered their instructional strategies with technology and performed well. The effectiveness of the TPD program for developing TPACK was determined. This analytical result is similar to that obtained by Boling and Beatty (2012), who used a cognitive apprenticeship model (CAM) to develop a teachers' learning environment for developing TPACK. According to Collins (2006, p. 48), the CAM is grounded in the belief that individuals learn in academic environments. It is designed to bring cognitive processes into the open, where learners can observe and enact, and. This study conducted a TPD program that provided all participants with an opportunity for peer observation and self-reflection with the final goal of improving student achievement. Moreover, teachers may transform their perspectives on technology integration and practice innovative teaching activities based on self-reflection results.

In this study, similar to CAM, experienced teachers who may have superior technology skills or instructional strategies combined $\mathrm{CK}, \mathrm{PK}$, and TK and used alternative teaching methods in the classroom, allowing other 
teachers to reflect on their own teaching practices. During the FGIs, teachers shared their perspectives and typically sought to learn collectively to achieve desirable results through dialogue, consensus, and sharing information. All teachers encountered cognitive apprenticeship processes and reorganized TPACK through the TPD program. Teaching activities that apply TPACK are clearly student centered.

\section{Conclusions and Discussion}

Analytical results acquired by this study indicate that participant teachers changed their beliefs and teaching practices about technology integration. During the initial stage, teachers' instructional strategies with technology were limited to lecturing. To achieve desirable professional development, teachers tried to utilize living technology and transform various technological skills into teaching activities with technology. Thus, teachers applied PK basis to content learning. Moreover, two experienced teachers used adequate teaching activities that combined PK, CK, and TK, providing other teachers with opportunities to reflect on their own instruction. Finally, teachers innovated collaboratively in applying TPACK, and they tended to use student-centered learning with technology. This change was due to their participation in the well-designed TPD program, in which teachers practiced instruction, peer observation, interaction, and dialogue. In terms of instructional strategies in developing TPACK, teachers initially expanded their limited PK by using living technology, such as a digital camera, and then combined subject content and TPACK. Afterward, they applied PK basis and combined subject content and technology through the TPD program, further reorganizing their application of TPACK.

These conclusions suggest that various technological functions can facilitate a teacher's development of TPACK; however, this may be insufficient to induce teachers to integrate technology and instruction, especially for those teachers who lack access to technological equipment or have poor technological skills. For most teachers whose PK and CK exceeded their TK, considering various instructional strategies or subject content and then seeking suitable technology to develop their idea of TPACK through the TPD program are feasible tasks. Moreover, several studies explored teaching approaches in applying TPACK through such quantitative questions as "I know how to teach by combining the technology, pedagogy, and content knowledge domains successfully" (e.g., Ergodan \& Sahin, 2010). This study further described the change to instructional strategies of teachers in applying TPACK concepts.

As literature described (Snoeyink \& Ertmer, 2002; Zhao \& Cziko, 2001), teachers initially acquire primary TK, including technology competencies and basic software skills, and then use technology to implement student-centered learning while they become familiar with technology (Ertmer, 2005; Windschitl \& Sahl, 2002). Thus, using technology can gradually enhance a teacher's instructional practices and effectively enhance that teacher's use of technology as a learning tool (Cooley, 2001; Snoeyink, \& Ertmer, 1999). Notably, a teacher's application of TK can expand that teacher's PK, and may generate multiple TPK-based activities. For the last two decades, technology has been established at various schools and teachers have been equipped with technology knowledge and skills. An increasing number of innovative technologies with various functions generate many ideas for teachers. Although these ideas are not yet confirmed, some teachers may use a couple of functions during teaching. Along with innovative technology use, teachers may implement different instructional strategies, ranging from lecturing, providing students with opportunities to utilize technology for learning, such as Internet searches, to collaborative learning using a digital camera. Moreover, technology integration should advance student learning rather than technology use itself. However, this study proposes that intentional technology use may help teachers integrate technology and student-centered teaching. I propose that a teacher's application of TK expands that teacher's PK, and answers the question about whether TPACK can help teachers implement student-centered instruction.

This study also suggests that the TPD program increases participant competency in applying TPACK; this finding is similar to that acquired by previous studies (Mishra, et al., 2010; Mouza \& Wong, 2009; Niess, et al., 2010). Initially, the PK of teachers was limited. However, through the four lesson periods, teachers increased their technology integration skills via observations and group interviews, especially those teachers who had poor technological skills. As in a study by Inan et al. (2010), teachers examined relationships between computer applications and classroom practices after observing their colleagues teach with technology and practice innovative teaching in their classrooms. This study identifies the effectiveness of peer observation and FGIs in a collaborative TPD program.

Teachers in this study, as mentioned, lectured to students using digital materials during the initial lesson period. Based on studies by Eteokleous (2008) and Hinostroza, Labbé, Brun \& Matama (2011), most in-service teachers should be equipped with the ability for technology integration, especially for student-centered teaching with technology, via TPD programs. However, as opposed to technology skills training, teachers may have few 
opportunities to promote their professional skills for student-centered learning with technology during in-service days. In this study, a teacher designed several activities that included a group discussion, using a camera, and searching the Internet. Other teachers reflected on their own instruction after classroom observation and then practiced innovative teaching that combines CK, TK, and PK. The collaborative TPD program can promote the professional skills of teachers. This study confirms that teachers can be equipped with the ability to practice student-centered teaching with technology through the TPD program, and examines teachers' instructional strategies in expanding, transforming, and reorganizing the application of TPACK.

According to Liu (2011), an overwhelming majority of teachers in Taiwan have basic technology skills and abilities for technology integration, and most teachers have utilized technology in their classrooms. However, most teachers implement lectured-based teaching activities when using technology. That is, technology integration would be insufficient and lack meaningful practices; this may be related to an inadequate understanding of technology integration. The collaborative TPD can benefit the thoughts and practices of teachers that are related to meaningful use of technology. This study provides teachers who are interested in examining teachers' TPACK with an effective TPD program that meets the needs of current elementary school settings. Additionally, two study findings are highlighted, and in turn, can be used to generate recommendations that continually enhance a teacher's TK and further promote TPACK through collaborative TPD programs. Moreover, this study indicates that teachers' TK expands their TPK. Further research is needed to confirm the relationship between teachers' TK and TPK.

\section{References}

Angeli, C., \& Valanides, N. (2009). Epistemological and methodological issues for the conceptualization, development, and assessment of ICT-TPCK: Advances in technological pedagogical content knowledge (TPCK). Computers \& Education, 52(1), 154-168. http://dx.doi.org/10.1016/j.compedu.2008.07.006

Archambault, L. M., \& Barnett, J. H. (2010). Revisiting technological pedagogical content knowledge: Exploring the TPACK framework. Computers \& Education, 55(4), 1656-1662. http://dx.doi.org/10.1016/j.compedu.2010.07.009

Archambault, L., \& Crippen, K. (2009). Examining TPACK among K-12 online distance educators in the United States. Contemporary Issues in Technology and Teacher Education, 9(1), 71-88.

Bauer, J., \& Kenton, J. K. (2005). Toward technology integration in the schools: Why it isn't happening. Journal of Technology and Teacher Education, 13(4), 519-546.

Birman, B., Desimone, Garet, M., \& Porter, A. (2000). Designing professional development that works. Educational Leadership, 57(8), 28-33.

Boling, E. C., \& Beatty, J. (2012). Overcoming the tensions and challenges of technology integration: How can we best support our teachers? In Ronau, R., Rakes, C., \& Niess, M. (Eds.), Educational Technology, Teacher Knowledge, and Classroom Impact: A Research Handbook on Frameworks and Approaches (pp. 136-156). Hershey, PA: IGI Global.

Chai, C. S., Koh, J. H. L., Tsai, C. C., \& Tan, L. L. W. (2011). Modeling primary school pre-service teachers' Technological Pedagogical Content Knowledge (TPACK) for meaningful learning with information and communication technology (ICT). Computers \& Education, 57(1), 1184-1193. http://dx.doi.org/10.1016/j.compedu.2011.01.007

Collins, A. (2006). Cognitive apprenticeship. In Sawyer, R. K. (Ed.), The Cambridge handbook of the learning sciences (pp. 47-60). New York, NY: Cambridge University Press.

Cooley, V. E. (2001). Implementing technology using the teachers as trainers staff development model. Journal of Technology and Teacher Education, 9(2), 269-284.

Ertmer, P. A. (1999). Addressing first- and second-order barriers to change: Strategies for technology integration. Educational Technology Research and Development, 47(4), 47-61. http://dx.doi.org/10.1007/BF02299597

Ertmer, P. A. (2005). Teacher pedagogical beliefs: The final frontier in our quest for technology integration? Educational Technology Research \& Development, 53(4), 25-39. http://dx.doi.org/10.1007/BF02504683

Eteokleous, N. (2008). Evaluating computer technology integration in a centralized school system. Computers \& Education, 51(2), 669-686. http://dx.doi.org/10.1016/j.compedu.2007.07.004

Gülbahar, Y. (2007). Technology planning: A roadmap to successful technology integration in schools. Computers \& Education, 49(4), 943-956. http://dx.doi.org/10.1016/j.compedu.2005.12.002 
Güyer, T., \& Sahin, S. (2011). Sharing teacher experiences of teaching with technology in the classroom: Analysis, design and development process of a web-based case library. Procedia - Social and Behavioral Sciences, 15, 3932-3940. http://dx.doi.org/10.1016/j.sbspro.2011.04.397

Harrington, R. A. (2008). The development of pre-service teachers' technology specific pedagogy. Unpublished doctoral dissertation, Oregon State University.

Harris, J. B., \& Hofer, M. J. (2011). Technological Pedagogical Content Knowledge (TPACK) in action: A descriptive study of secondary teachers' curriculum-based, technology-related instructional planning. Journal of Research on Technology in Education, 43(3), 211-229.

Hewitt, J. (2008). Reviewing the handbook of technological pedagogical content knowledge (TPCK) for educators. Canadian Journal of Science, Mathematics, and Technology Education, 8(4), 355-360. http://dx.doi.org/10.1080/14926150802506274

Hinostroza, J. E., Labbé, C., Brun, M., \& Matama, C. (2011). Teaching and learning activities in Chilean classrooms: Is ICT making a difference? Computers \& Education, 57(1), 1358-1367. http://dx.doi.org/10.1016/j.compedu.2011.01.019

Inan, F. A., Lowther, D. L., Ross, S., \& Strahl, J. D. (2010). Pattern of classroom activities during students use of computers: Relations between instructional strategies and computer applications. Teaching and Teacher Education, 26 (3), 540-546. http://dx.doi.org/10.1016/j.tate.2009.06.017

Jang, S. J. (2008). The effects of integrating technology, observation and writing into a teacher education method course. Computers \& Education, 50(3), 853-865. http://dx.doi.org/10.1016/j.compedu.2006.09.002

Jang, S. J. (2010). Integrating the interactive whiteboard and peer coaching to develop the TPACK of secondary $\begin{array}{lllll}\text { science teachers. Computers \& } \quad \text { Education, } & \text { 55(4), }\end{array}$ http://dx.doi.org/10.1016/j.compedu.2010.07.020

Jang, S. J., \& Tsai, M. F. (2012). Exploring the TPACK of Taiwanese elementary mathematics and science teachers with respect to use of interactive whiteboards. Computers \& Education, 59(2), 327-338. http://dx.doi.org/10.1016/j.compedu.2012.02.003

Jimoyiannis, A. (2010). Designing and implementing an integrated Technological Pedagogical Science Knowledge framework for science teacher's professional development. Computers \& Education, 55(3), 1259-1269. http://dx.doi.org/10.1016/j.compedu.2010.05.022

Jonassen, D. H., Howland, J., Moore, J., \& Marra, R. M. (2003). Learning to solve problems with technology: A constructivist perspective (2ed.). New Jersey: Prentice-Hall.

Koehler, M. J., \& Mishra, P. (2009). What is technological pedagogical content knowledge? Contemporary issues in technology and teaching education, 9(1), 60-70.

Koehler, M. J., Mishra, P., \& Yahya, K. (2007). Tracing the development of teacher knowledge in a design seminar: Integrating content, pedagogy and technology. Computers \& Education, 49(3), 740-762. http://dx.doi.org/10.1016/j.compedu.2005.11.012

Liu, S. H. (2011). Factors related to pedagogical beliefs of teachers and technology integration. Computers \& Education, 56(4), 1012-1022. http://dx.doi.org/10.1016/j.compedu.2010.12.001

Mishra, P., \& Koehler, M. J. (2006). Technological pedagogical content knowledge: A framework for teacher $\begin{array}{llll}\text { knowledge. Teaches } & \text { College 108(6), Record, }\end{array}$ http://dx.doi.org/10.1111/j.1467-9620.2006.00684.x

Mishra, P., Koehler, M. J., Shin, T. S., Wolf, L. G., \& DeSchryver, M. (2010). Developing TPACK by design. In J. Voogt (Ed.), Developing TPACK. Symposium conducted at the annual meeting of the Society for Information Technology and Teacher Education (SITE), San Diego, CA.

Mouza, C., \& Wong, W. (2009). Studying classroom practice: Case development for professional learning in technology integration. Journal of Technology and Teacher Education, 17(2), 175-202.

Niess, M. L. (2005). Preparing teachers to teach science and mathematics with technology: Developing a technology pedagogical content knowledge. Teaching and Teacher Education, 21, 509-523. http://dx.doi.org/10.1016/j.tate.2005.03.006

Niess, M. L. (2011). Investigating TPACK: Knowledge growth in teaching with technology. Journal of Educational Computing Research, 44(3), 299-317. http://dx.doi.org/10.2190/EC.44.3.c 
Niess, M. L. (2012). Teacher Knowledge for Teaching with Technology: A TPACK Lens. In R. Ronau, C. Rakes, \& M. Niess (Eds.), Educational technology, teacher knowledge, and classroom impact: A research handbook on frameworks and approaches (pp. 1-15). British: IGI Global.

Niess, M. L., van Zee, E. H., \& Gillow-Wiles, H. (2010). Knowledge growth in teaching Mathematics/Science with spreadsheets: Moving PCK to TPACK through Online professional development. Journal of Digital Learning in Teacher Education, 27(2), 42-52.

Overbaugh, R., \& Lu, R. (2008). The impact of a NCLB-EETT funded professional development program on teacher self-efficacy and resultant implementation. Journal of Research on Technology in Education, 41(1), 43-61.

Park, C. N., \& Son, J. B. (2009). Implementing computer-assisted language learning in the EFL classroom: Teachers' perceptions and perspectives. International Journal of Pedagogies \& Learning, 5(2), 80-101. http://dx.doi.org/10.5172/ijpl.5.2.80

Schmidt, D. A., Baran E., Thompson A. D., Mishra P., Koehler M. J., \& Shin T. S. (2009). Technological Pedagogical Content Knowledge (TPACK): The development and validation of an assessment instrument for preservice teachers. Journal of Research on Technology in Education, 42, 123-150.

Shulman, L. S. (1986). Those who understand: Knowledge growth in teaching. Educational Researcher, 15(2), 4-14. http://dx.doi.org/10.3102/0013189X015002004

Snoeyink, R., \& Ertmer, P. A. (2002). Thrust into technology: How veteran teachers respond. Educational Administration Abstracts, 37(3), 279-412.

Van Braak, J. (2001). Factors influencing the use of computers mediated communication by teachers in $\begin{array}{llllll}\text { secondary education. } \quad \text { Computers } \quad \& \quad \text { Education, } & 36(1), & \text { 41-57. }\end{array}$ http://dx.doi.org/10.1016/S0360-1315(00)00051-8

Windschitl, M., \& Sahl, K. (2002). Tracing teachers' use of technology in a laptop computer school: The interplay of teacher beliefs, social dynamics and institutional culture. American Educational Research Journal, 39(1), 165-205. http://dx.doi.org/10.3102/00028312039001165

Yalçın, A., \& Yalçın, N. (2010). How to get best result from a presentation? How to increase effectiveness of a presentation? Procedia- Social and Behavioral Sciences, 9, 480-486.

Zhao, Y., \& Cziko, G. A. (2001). Teacher adoption of technology: A perceptual control theory perspective. Journal of Technology and Teacher Education, 9(1), 5-30.

\section{Copyrights}

Copyright for this article is retained by the author(s), with first publication rights granted to the journal.

This is an open-access article distributed under the terms and conditions of the Creative Commons Attribution license (http://creativecommons.org/licenses/by/3.0/). 